ISSN 1392-3196 / e-ISSN 2335-8947

Zemdirbyste-Agriculture, vol. 100, No. 2 (2013), p. 143-150

DOI 10.13080/z-a.2013.100.018

\title{
Evaluation of fermentation parameters, microbiological composition and aerobic stability of grass and whole crop maize silages treated with microbial inoculants
}

\author{
Jonas JATKAUSKAS, Vilma VROTNIAKIENE \\ Institute of Animal Science, Lithuanian University of Health Sciences \\ R. Žebenkos 12, Baisogala, Radviliškis distr., Lithuania \\ E-mail: lgipts@gmail.com
}

\begin{abstract}
Two experiments were conducted in 2011-2012 to evaluate the fermentation parameters, microbiological composition and aerobic stability of grass and whole crop maize silages treated with microbial inoculants, different blends of the selected bacterial strains and blend of the selected bacterial strains in combination with sodium benzoate. Wilted ryegrass:timothy and whole crop maize with 265 and $276 \mathrm{~g} \mathrm{~kg}^{-1}$ dry matter (DM) content were ensiled in 3 litre laboratory silos. The mean water soluble carbohydrate (WSC) concentration, buffer capacity and nitrate concentration in ryegrass:timothy and whole crop maize were 101.8 and $98.9 \mathrm{~g} \mathrm{~kg}^{-1} \mathrm{DM}, 355$ and 217 $\mathrm{mEq} \mathrm{kg}{ }^{-1} \mathrm{DM}$, and 153.2 and $841.1 \mathrm{mg} \mathrm{kg}^{-1} \mathrm{DM}$, respectively. Silages treated with the tested inoculants were characterized by higher concentrations of DM compared with the untreated silage. Ryegrass:timothy and maize herbage inoculant treatments before ensiling significantly decreased $(P<0.05) \mathrm{pH}$, significantly reduced butyric acid, ammonia-N concentrations and DM loss compared with control silage. Ryegrass:timothy and maize silages inoculated with homofermentative bacteria blends produce higher $(P<0.05)$ lactic acid compared with that of the control silage. Butyric acid, alcohols and $\mathrm{N}_{-} \mathrm{NH}_{3}$ fraction concentrations were significantly $(P<0.05)$ decreased by inoculation. When compared with control silage, increased $(P<0.05)$ acetic acid concentration and decreased lactic acid concentration were observed in ryegrass:timothy silages and maize silages inoculated with heterofermentative lactic acid bacteria (LAB) strain Lactobacillus buchnery. The LAB blends used in our experiment significantly suppressed yeast and moulds growth reflected in the lower concentration of alcohols, generally correlated to yeast activity in silages. Inoculation increased the aerobic stability of ryegrass:timothy and maize silages, compared with control silage. The aerobic stability of inoculated ryegrass:timothy and maize silages was improved by $66-312$ hours compared to control silage.
\end{abstract}

Key words: aerobic stability, fermentation, maize, microbial inoculant, ryegrass, silage, timothy.

\section{Introduction}

Milk and beef meat production systems in different climatic zones have been developed to utilize local feed resources. Due to the short grazing period (140-150 days) in Lithuania grazed grass cannot contribute more than $30-35 \%$ of the total feed energy for cattle. This has increased the importance of conserved forages in dairy cows and fattening cattle rations.

Progress in improving silage quality and nutrient use efficiency is influenced by a number of factors, but as implied from the above account, advances in plant breeding and additives for manipulating silage fermentation and ruminal processes present interesting opportunities (Davies et al., 2005). A wide variety of additives were evaluated for their efficacy as preservatives; however, bacterial inoculants were topical during the last two decades and their potential to improve silage fermentation (Filya et al., 2007), and animal productivity was widely demonstrated (Contreras-Govea et al., 2009). Selection of effective bacteria strains and bacteria blends for the use as inoculants is crucial for successful ensiling (Saarisalo et al., 2007). The lactic acid bacteria
(LAB) inoculant strains have been selected for rapid growth under wide range of temperatures and dry matter concentrations. These strains are highly competitive and produce largely lactic acid, reducing $\mathrm{pH}$ compared to untreated silage (Muck, 2012). However, most well preserved and energy rich silages are prone to aerobic deterioration after opening. When oxygen is introduced to silage, aerobic microorganisms begin to grow, initially respiring soluble substrates and then more complex compounds. Yeasts are generally the initiators of aerobic deterioration, consuming sugars, fermentation acids and raising silage temperature (Pahlow et al., 2003). Finally, moulds complete the deterioration of the silages (Dolci et al., 2011). There is evidence that aerobic deterioration generates an accumulation of degradation products or changes in volatiles (Krizsan, Randby, 2007; Weib et al., 2011) and could affect feed intake negatively. Wichert et al. (1998) concluded that dairy cows fed on silage of poor hygienic quality that had undergone deterioration after being exposed to air showed a decrease in forage intake of about $10 \%$ to $20 \%$ in comparison to fresh silage. Some 
inoculant LAB strains produce anti-microbial compounds that inhibit mould growth or undesirable bacterial species like Salmonella sp., Listeria sp. and Escherichia coli (Gollop et al., 2005). Kleinschmitt et al. (2005) indicated that improved aerobic stability was observed in different types of forages when acetic acid and propionic acid production in silage fermentation increased with $L$. buchneri inoculation. In the study (Jatkauskas et al., 2013), selected LAB inoculants were efficient in improving fermentation, reducing protein breakdown and nutrient losses of grass, clover-grass, lucerne and maize silages. Homofermentative LAB in combination with sodium benzoate led to silages with higher lactic acid content, when inoculation with single heterofermentative LAB or with mixture of homo-and heterofermentative LAB resulted in higher levels of acetic acid. An enhancement of aerobic stability by additive application was obtained in all inoculated silages. Single strain L. buchneri was more effective in improving aerobic stability of silages.
The objectives of this experiment were to evaluate the effects of the inoculants containing new combination of homofermentative and heterofermentative lactic acid-producing bacteria strains with either no other components or with sodium benzoate on fermentation end-products, microbial population and aerobic stability in grass and maize silages.

\section{Materials and methods}

Experiments were conducted in 2011-2012 at Institute of Animal Science, Lithuanian University of Health Sciences according to the DLG (Deutsche Landwirtschafts-Gesellshaft e.V./ internationally acknowledged German Agricultural Society) Guidelines for the testing of silage additives.

Test material. The lactic acid bacteria (LAB) strains rather than formulations were registered as silage additives in the European Union. Therefore, trade names are not provided in Table 1.

Table 1. Inoculants used in the experiments

\begin{tabular}{|c|c|c|c|c|}
\hline Inoculant & Inoculant composition & $\begin{array}{c}\text { Proportion } \\
\%\end{array}$ & $\begin{array}{l}\text { Concentration } \\
\text { cfu g }^{-1} \text { product }\end{array}$ & 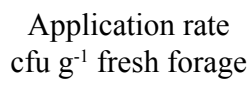 \\
\hline $\mathrm{P} 0$ & Lactobacillus buchneri CCM 1819 & 100 & $2.4 \mathrm{E}+11$ & 150000 \\
\hline $\mathrm{P} 1$ & $\begin{array}{c}\text { Lactobacillus plantarum DSM16568 } \\
\text { Entrococcus faecium NCIMB } 11181 \\
\text { Lactobacillus buchneri CCM } 1819\end{array}$ & $\begin{array}{l}20 \% \\
30 \% \\
50 \%\end{array}$ & $2.8 \mathrm{E}+11$ & 150000 \\
\hline $\mathrm{P} 2 \mathrm{a}$ & $\begin{array}{c}\text { Lactobacillus plantarum DSM16568 } \\
\text { Entrococcus faecium NCIMB } 11181 \\
\text { Lactococcus lactis DSM } 11037 \\
\text { Sodium benzoate at } 400 \mathrm{~g} \mathrm{ton}^{-1} \text { forage* }\end{array}$ & $\begin{array}{l}30 \% \\
40 \% \\
30 \%\end{array}$ & $2.29 \mathrm{E}+11$ & 150000 \\
\hline $\mathrm{P} 2 \mathrm{~b}$ & $\begin{array}{c}\text { Lactobacillus plantarum DSM16568 } \\
\text { Entrococcus faecium NCIMB } 11181 \\
\text { Lactococcus lactis DSM } 11037\end{array}$ & $\begin{array}{l}30 \% \\
40 \% \\
30 \%\end{array}$ & $2.29 \mathrm{E}+11$ & 150000 \\
\hline P3 & $\begin{array}{c}\text { Entrococcus faecium NCIMB } 11181 \\
\text { Lactococcus lactis NCIMB } 30117 \\
\text { Lactobacillus plantarum DSM } 16568\end{array}$ & $\begin{array}{l}30 \% \\
30 \% \\
40 \%\end{array}$ & $2.4 \mathrm{E}+10$ & 150000 \\
\hline P4 & $\begin{array}{l}\text { Lactobacillus plantarum DSM16568 } \\
\text { Lactobacillus plantarum DSM } 18112\end{array}$ & $\begin{array}{l}50 \% \\
50 \%\end{array}$ & $1.4 \mathrm{E}+11$ & 100000 \\
\hline
\end{tabular}

cfu - colony forming units, * - sodium benzoate was added separately

Inoculants were supplied by "Chr. Hansen A/S" ("Hørsholm", Denmark) as freeze-dried powders in sealed aluminium pouches clearly labelled. The test materials were stored at temperatures below $5^{\circ} \mathrm{C}$ until used. Opened pouches were discarded after use.

Crop material and micro-silo preparation. A mixture of perennial ryegrass (Lolium perenne L.) and timothy (Phleum pratense L.) (ryegrass:timothy) (70:30 on fresh weight basis) at 2-year-old, second cut, at the early bloom stage of maturity of red clover and whole crop maize (Zea mays L.) at the one-third milk line stage of maturity were used in the present experiments. The ryegrass:timothy was harvested in mid August. The crop was cut by a mower conditioner "Kverneland Taarup 347" ("Kverneland Group", Norway), wilted to a DM concentration of $265 \mathrm{~g} \mathrm{~kg}^{-1}$ and chopped by a forage harvester to $2-3 \mathrm{~cm}$ length under farm conditions. The whole crop maize cultivar 'Baxxos FAO 200' was harvested in the beginning of October. Whole crop maize was harvested and chopped at the one-third milk line stage of maturity (a DM concentration of $276 \mathrm{~g} \mathrm{~kg}^{-1}$ ) with a maize harvester "CLASS JAGUAR 840" ("Class group", Germany) to a length of $2-3 \mathrm{~cm}$. Laboratory experiments started within $2 \mathrm{~h}$ from crop preparation. Six silage inoculants were used in the experiments and 140 micro-silos (70 ryegrass:timothy and 70 whole crop maize), 20 untreated and 120 inoculated were ensiled.

The test materials were suspended in distilled water immediately prior to application targeting a dosage of $1.5 \times 10^{8} \mathrm{cfu} \mathrm{ml}^{-1}$ of suspension for the products 0,1 , $2 \mathrm{a}, 2 \mathrm{~b}$ and 3 and $-1.0 \times 10^{8} \mathrm{cfu} \mathrm{ml}^{-1}$ of suspension for the product 4 . The application rates of the inoculants were in accordance with the level of LAB in the inoculants as determined by manufacturer and in accordance with Table 1, column 5. Additionally, $400 \mathrm{~g}$ sodium benzoate for $\mathrm{P} 2 \mathrm{a}$ was diluted in 1 litre of distilled water. The same volume ( $4 \mathrm{ml} \mathrm{g}^{-1}$ of fresh forage) of chlorine-free water was used instead of the suspension in the control treatment (for spontaneous fermentation). The number of viable bacteria in each suspension used for inoculating the micro-silos was counted on DeMan-Rogosa-Sharpe (MRS) agar (ISO 15214, Leuschner et al., 2003). Threelitre glass jars were used in the experiment. The density of forage in the mini-silages was in compliance with 
DLG recommendations, $1 \mathrm{~kg}$ DM per 5 litre volume. The silos were capped with a lid enabling gas release $30 \mathrm{~min}$ after being filled. Ensiling lasted for 90 days at a constant temperature of $20^{\circ} \mathrm{C}$.

Sampling and analysis. Five representative samples $(>500 \mathrm{~g})$ of each chopped forage were collected for subsequent chemical and microbiological composition analysis. At the sampling time of silages on day 90 of the ensiling period, five micro-silos per treatment and crop (70 micro-silos) were weighed for determination of DM loss and subsequently opened and sampled to analyze the DM content, $\mathrm{pH}$, fermentation products and ammonia-N. The remaining 70 micro-silos (5 from each treatment and crop) were used for aerobic stability measurement. The fermentation loss was calculated as the difference between the initial and final weight. Samples of ensiled material in 0.7-litre silo (5 from each field and each treatment) were subjected for $\mathrm{pH}$-value tests 3 days after ensiling for ryegrass:timothy and 2 days after ensiling for whole crop maize.

The DM content of forage and silage, chemical composition, volatile fatty acids, lactic acid and alcohols concentrations were determined as described previously by Jatkauskas et al. (2013).

Presence of Clostridium perfringens was quantified on reinforced clostridium agar Petri dishes incubated anaerobically at $37^{\circ} \mathrm{C}$ for $72 \mathrm{~h}$ (horizontal method for the enumeration of $C$. perfringens - colonycount technique (ISO 7937:2004). Amount of lactatereducing yeasts and moulds at the time of silage unloading was tested on extract-dextrose-chloramphenicol-agarmedium Petri dishes incubated aerobically at $25^{\circ} \mathrm{C}$ for 3 to 5 days (microbiology - general guidance for enumeration of yeasts and moulds - colony-count technique at $25^{\circ} \mathrm{C}$ (ISO 7954:1987(E)).

After opening the micro-silos, all silages were subjected to an aerobic stability test. A $1000 \pm 10 \mathrm{~g}$ sample from each silo (five silos from each treatment and crop) was loosely placed into a polystyrene box according to recommendations from DLG and allowed to aerobically deteriorate at constant room temperature $\left(20^{\circ} \mathrm{C}\right)$. A transducer was placed in the centre of the silage mass through a hole in the cover of the box, which exposed the silage to air. These silages were not disturbed during the period of recording the temperatures. Ambient temperature and the temperature of each silage was recorded every $6 \mathrm{~h}$ by a data logger. Ambient room temperature was measured by using an empty control box. Aerobic stability of silages was examined by calculating the differences between silage temperature and ambient room temperature adjusted for base ambient temperature. Aerobic stability was defined as the number of hours the silage remained stable before rising more than $3^{\circ} \mathrm{C}$ above the ambient temperature (Moran et al., 1996).

Statistical analysis. Silage composition data were subjected to one-way analysis of variance for a 7 (additive) factorial arrangement of treatments within a randomized complete block design by using Proc $G L M$ of $S A S$, version 8.02 (Statistical Analysis System, 2000). Aerobic stability data for each crop type were analyzed separately by one-way analysis of variance in a randomized complete block design and where temperatures were treated as repeated measurements. Significance of the differences between the means was determined according to the least significant difference (LSD) at 0.05 probability level.

\section{Results}

Chemical and microbiological composition of herbage. The mean chemical and microbiological composition of the ryegrass:timothy and whole crop maize at ensiling is summarized in Table 2. Ryegrass:timothy grass was wilted up to $265 \mathrm{~g} \mathrm{~kg}^{-1}$ of dry matter. The concentration of WSC was medium $\left(101.8 \mathrm{~g} \mathrm{~kg}^{-1} \mathrm{DM}\right)$ and the crude protein content was medium too $\left(171.6 \mathrm{~g} \mathrm{~kg}^{-1}\right.$ $\mathrm{DM})$. The buffering capacity was typical of grass herbage (355 mEq kg-1 DM). Consequently, ryegrass:timothy was characterized as moderately difficult to ensile.

Table 2. Mean chemical composition and microbiological composition of herbage at ensiling $\left(\mathrm{g} \mathrm{kg}^{-1} \mathrm{DM}\right)$

\begin{tabular}{|c|c|c|c|c|c|}
\hline \multirow{2}{*}{ Variable } & \multirow{2}{*}{$\mathrm{n}$} & \multicolumn{2}{|c|}{ Ryegrass:timothy $(70: 30)$} & \multicolumn{2}{|c|}{ Whole crop maize } \\
\hline & & Mean & Std & Mean & Std \\
\hline $\mathrm{DM}$ & 5 & 264.6 & 5.5 & 275.9 & 12.0 \\
\hline Crude protein & 5 & 171.6 & 7.2 & 88.8 & 4.8 \\
\hline Crude ash & 5 & 87.2 & 1.3 & 50.1 & 2.5 \\
\hline WSC & 5 & 101.8 & 6.0 & 98.9 & 3.7 \\
\hline $\mathrm{ADF}$ & 5 & 319.2 & 18.1 & 265.4 & 10.3 \\
\hline NDF & 5 & 493.3 & 12.5 & 466.7 & 10.4 \\
\hline $\mathrm{pH}$ & 5 & 6.3 & 0.0 & 5.7 & 0.2 \\
\hline Nitrate, $\mathrm{mg} \mathrm{kg}^{-1} \mathrm{DM}$ & 5 & 153.2 & 17.4 & 841.1 & 53.7 \\
\hline Buffer capacity, $\mathrm{mEq} \mathrm{kg}{ }^{-1} \mathrm{DM}$ & 5 & 355 & 4.8 & 217 & 1.0 \\
\hline Clostridia, log cfu g $\mathrm{g}^{-1} \mathrm{FM}$ & 5 & $<1.0$ & 0 & $<1.0$ & 0 \\
\hline Yeast, log cfu $\mathrm{g}^{-1} \mathrm{FM}$ & 5 & 3.8 & 1.2 & 4.3 & 0.5 \\
\hline Moulds, $\log \mathrm{cfu} \mathrm{g}^{-1} \mathrm{FM}$ & 5 & 4.9 & 0.4 & 4.6 & 0.6 \\
\hline
\end{tabular}

$\mathrm{DM}$ - dry matter, WSC - water-soluble carbohydrate, ADF - acid detergent fibre, NDF - neutral detergent fibre, FM - fresh matter; $\mathrm{cfu}$ - colony forming units

Whole crop maize contained medium dry matter concentration $\left(276 \mathrm{~g} \mathrm{~kg}^{-1}\right)$, soluble carbohydrates concentration was medium (98.9 $\left.\mathrm{g} \mathrm{kg}^{-1} \mathrm{DM}\right)$ and crude protein content was low $\left(88.8 \mathrm{~g} \mathrm{~kg}^{-1} \mathrm{DM}\right)$. The buffering capacity was typical of maize herbage $\left(217 \mathrm{mEq} \mathrm{kg}^{-1} \mathrm{DM}\right)$.
Consequently, whole crop maize was characterized as easy to ensile. The ryegrass:timothy and maize for ensiling was low in clostridia count and moderately contaminated by yeast and moulds. The crude protein, crude ash, ADF, $\mathrm{NDF}, \mathrm{pH}$, buffer capacity and mould values were higher, 
and nitrate, organic matter digestibility and yeast values were lower for ryegrass:timothy compared to whole crop maize herbage.

Water and suspension analyses. Enumeration test of the control water and the water (suspensions) with the addition of products used for inoculating of the ryegrass:timothy and whole crop maize silages indicate that sufficient amounts of each inoculant were applied to forage to obtain the desired rates of inoculation (Table 3 ).

Table 3. Bacteria counts in water and suspension used for silage inoculation, $\mathrm{cfu} \mathrm{ml}^{-1}$

\begin{tabular}{|c|c|c|c|c|c|}
\hline \multirow{2}{*}{ Variable } & \multirow{2}{*}{ Expected counts } & \multicolumn{4}{|c|}{ Actual counts } \\
\hline & & ryegrass:timothy & $\pm \%$ & whole crop maize & $\pm \%$ \\
\hline Water & 0 & $<1.0 \times 10^{2}$ & & $<1.0 \times 102$ & \\
\hline P0 & $1.5 \times 10^{8}$ & $1.6 \times 10^{8}$ & $+6.7 \%$ & $1.8 \times 10^{8}$ & $+12.0 \%$ \\
\hline $\mathrm{P} 1$ & $1.5 \times 10^{8}$ & $1.7 \times 10^{8}$ & $+13.3 \%$ & $1.4 \times 10^{8}$ & $-6.7 \%$ \\
\hline $\mathrm{P} 2 \mathrm{a}$ & $1.5 \times 10^{8}$ & $1.6 \times 10^{8}$ & $+6.7 \%$ & $1.9 \times 10^{8}$ & $+26.7 \%$ \\
\hline $\mathrm{P} 2 \mathrm{~b}$ & $1.5 \times 10^{8}$ & $1.7 \times 10^{8}$ & $+13.3 \%$ & $1.5 \times 10^{8}$ & 0 \\
\hline P3 & $1.5 \times 10^{8}$ & $1.7 \times 10^{8}$ & $+13.3 \%$ & $1.6 \times 10^{8}$ & $+6.7 \%$ \\
\hline P4 & $1.0 \times 10^{8}$ & $1.1 \times 10^{8}$ & $+10.0 \%$ & $1.0 \times 10^{8}$ & 0 \\
\hline
\end{tabular}

$\mathrm{cfu}$ - colony forming units

Chemical and microbiological composition of silage. The results for all six products used for the cultivar of ryegrass:timothy treatment are presented in Table 4 .

Products used for the ryegrass:timothy silage inoculation (except inoculants P0 and P1) significantly increased dry matter content. Inoculants used for ryegrass:timothy inoculation significantly decreased DM loss (except P0) compared with control silage. All six treatments resulted in significant $(P<0.05) \mathrm{pH}$ drop after 3 days and after 90 days of ensiling compared with control. When compared with control silage, increased $(P<0.05)$ acetic acid concentrations were observed only in silage inoculated with $\mathrm{P} 0$. No significant differences in the lactic acid, butyric acid, propionic acid concentrations were detected between the untreated silage and silage treated with P0. Treatments P2a and P4 significantly decreased acetic acid concentration compared with control. Treatments $\mathrm{P} 1, \mathrm{P} 2 \mathrm{a}, \mathrm{P} 2 \mathrm{~b}, \mathrm{P} 3$ and $\mathrm{P} 4$ produced higher $(P<0.05)$ lactic acid concentration compared with that of the control silage. Butyric acid, alcohols and
$\mathrm{N}-\mathrm{NH}_{3}$ fraction concentrations, yeast and mould counts were significantly decreased $(P<0.05)$ by application of all inoculants. The ensiling characteristics of whole crop maize silages are shown in Table 5.

The quality of inoculated whole crop maize silages was significantly improved compared to that of the untreated, control silage. The blend of selected bacterial strains and the blend of selected bacterial strains in combination with sodium benzoate used for the whole crop maize silage inoculation (except inoculants $\mathrm{P} 0$ and P1) significantly increased dry matter content. All products used for inoculation ryegrass:timothy significantly decreased DM loss compared with control silage. All six treatments resulted in significant $(P<0.05) \mathrm{pH}$ drop after 2 days and after 90 days of ensiling compared with control. Treatment P0 decreased $(P<0.05)$ lactic acid concentration, increased $(P<0.05)$ acetic concentration compared with control silage. Treatment P1 had no effect on lactic acid formation, but increased $(P<0.05)$ acetic acid concentration compared to the control silage.

Table 4. Mean effects of the use of inoculants on ensiling quality and microbiological composition of ryegrass:timothy silages

\begin{tabular}{|c|c|c|c|c|c|c|c|c|}
\hline Variable & $\begin{array}{c}\text { No } \\
\text { additive }\end{array}$ & P0 & $\mathrm{P} 1$ & $\mathrm{P} 2 \mathrm{a}$ & $\mathrm{P} 2 \mathrm{~b}$ & $\mathrm{P} 3$ & P4 & $\mathrm{LSD}_{0.05}$ \\
\hline $\mathrm{DM}, \mathrm{g} \mathrm{kg}^{-1}$ & $250^{c}$ & $252^{\mathrm{b}, \mathrm{c}}$ & $252^{b, c}$ & $253^{\mathrm{b}, \mathrm{a}}$ & $254^{\mathrm{b}, \mathrm{a}}$ & $256^{\mathrm{a}}$ & $254^{\mathrm{b}, \mathrm{a}}$ & 2.563 \\
\hline DM, \% & $6,3^{\mathrm{a}}$ & $5.8^{\mathrm{b}, \mathrm{a}}$ & $5.2^{\mathrm{b}, \mathrm{c}}$ & $4.9^{\mathrm{d}, \mathrm{c}}$ & $4.5^{\mathrm{d}, \mathrm{e}}$ & $4.0^{\mathrm{e}}$ & $4.6^{\mathrm{d}, \mathrm{e}}$ & 0.671 \\
\hline $\mathrm{pH}$ after 3 days & $5.48^{\mathrm{a}}$ & $4.90^{\mathrm{b}}$ & $4.38^{\mathrm{e}}$ & $4.51^{\mathrm{d}, \mathrm{e}}$ & $4.70^{\mathrm{c}}$ & $4.45^{\mathrm{d}, \mathrm{e}}$ & $4.59^{\mathrm{d}, \mathrm{c}}$ & 0.142 \\
\hline pH after 90 days & $4.55^{\mathrm{a}}$ & $4.15^{\mathrm{b}}$ & $3.89^{\mathrm{d}}$ & $3.91^{\mathrm{d}}$ & $3.98^{\mathrm{c}}$ & $3.96^{\mathrm{c}}$ & $3.91^{\mathrm{d}}$ & 0.037 \\
\hline Ammonia- $\mathrm{N}, \mathrm{g} \mathrm{kg}^{-1} \mathrm{~N}$ & $60.2^{\mathrm{a}}$ & $51.0^{\mathrm{b}}$ & $49.2^{\mathrm{b}}$ & $43.6^{\mathrm{c}}$ & $42.6^{\mathrm{c}}$ & $40.6^{c}$ & $42.8^{\mathrm{c}}$ & 4.672 \\
\hline $\mathrm{LA}, \mathrm{g} \mathrm{kg}^{-1} \mathrm{DM}$ & $31.06^{\mathrm{d}}$ & $33.92^{\mathrm{d}}$ & $52.92^{\mathrm{c}}$ & $72.22^{\mathrm{a}}$ & $57.92^{\mathrm{c}}$ & $57.56^{\mathrm{c}}$ & $64.76^{\mathrm{b}}$ & 5.992 \\
\hline $\mathrm{AA}, \mathrm{g} \mathrm{kg}^{-1} \mathrm{DM}$ & $27.58^{\mathrm{c}, \mathrm{b}}$ & $45.62^{\mathrm{a}}$ & $25.96^{\mathrm{c}, \mathrm{b}, \mathrm{d}}$ & $18.48^{\mathrm{e}}$ & $24.84^{\mathrm{c}, \mathrm{d}}$ & $28.42^{\mathrm{b}}$ & $24.02^{\mathrm{d}}$ & 3.532 \\
\hline $\mathrm{BA}, \mathrm{g} \mathrm{kg}^{-1} \mathrm{DM}$ & $2.54^{\mathrm{a}}$ & $1.94^{\mathrm{a}, \mathrm{b}}$ & $1.62^{\mathrm{b}}$ & $0.70^{\mathrm{c}}$ & $0.64^{\mathrm{c}}$ & $0.44^{\mathrm{c}}$ & $0.74^{\mathrm{c}}$ & 0.757 \\
\hline $\mathrm{PA}, \mathrm{g} \mathrm{kg}^{-1} \mathrm{DM}$ & $0.16^{\mathrm{b}, \mathrm{a}}$ & $0.28^{\mathrm{a}}$ & $0.22^{\mathrm{b}, \mathrm{a}}$ & $0.12^{\mathrm{b}}$ & $0.12^{\mathrm{b}}$ & $0.14^{\mathrm{b}}$ & $0.10^{\mathrm{b}}$ & 0.127 \\
\hline $\mathrm{AL}, \mathrm{g} \mathrm{kg}^{-1} \mathrm{DM}$ & $6.98^{\mathrm{a}}$ & $5.86^{\mathrm{b}}$ & $5.46^{\mathrm{c}, \mathrm{b}}$ & $5.04^{\mathrm{c}, \mathrm{b}}$ & $4.84^{\mathrm{c}}$ & $4.96^{\mathrm{c}, \mathrm{b}}$ & $4.90^{\mathrm{c}}$ & 0.941 \\
\hline $\mathrm{CL}, \log _{10} \mathrm{cfu} \mathrm{g}^{-1} \mathrm{FM}$ & $0.99^{\mathrm{a}}$ & $0.99^{\mathrm{a}}$ & $0.99^{\mathrm{a}}$ & $0.99^{\mathrm{a}}$ & $0.99^{\mathrm{a}}$ & $0.99^{\mathrm{a}}$ & $0.99^{\mathrm{a}}$ & 0.004 \\
\hline $\mathrm{Y}, \log _{10} \mathrm{cfu} \mathrm{g}^{-1} \mathrm{FM}$ & $3.18^{\mathrm{a}}$ & $1.31^{\mathrm{b}}$ & $1.36^{\mathrm{b}}$ & $1.51^{\mathrm{b}}$ & $1.62^{\mathrm{b}}$ & $1.54^{\mathrm{b}}$ & $1.41^{\mathrm{b}}$ & 0.614 \\
\hline $\mathrm{M}, \log _{10} \mathrm{cfu} \mathrm{g}^{-1} \mathrm{FM}$ & $3.00^{\mathrm{a}}$ & $1.30^{\mathrm{b}}$ & $1.40^{\mathrm{b}}$ & $1.44^{\mathrm{b}}$ & $1.58^{\mathrm{b}}$ & $1.42^{\mathrm{b}}$ & $1.66^{\mathrm{b}}$ & 0.391 \\
\hline
\end{tabular}

Notes. DM and calculated DM losses are corrected for volatiles. ${ }^{\mathrm{a}, \mathrm{b}, \mathrm{c}, \mathrm{d}, \mathrm{e}}-$ means with different superscript letters in a line indicate significant differences of $P<0.05$. DM - dry matter, LA - lactic acid, AA - acetic acid, BA - butyric acid, PA - propionic acid, $\mathrm{AL}$ - alcohols, $\mathrm{CL}$ - clostridia, $\mathrm{Y}$ - yeast, $\mathrm{M}$ - moulds, $\mathrm{FM} \mathrm{-} \mathrm{fresh} \mathrm{matter;} \mathrm{cfu} \mathrm{-} \mathrm{colony} \mathrm{forming} \mathrm{units.}$ 
Table 5. Mean effects of the use of inoculants on ensiling quality and microbiological composition of whole crop maize silages

\begin{tabular}{|c|c|c|c|c|c|c|c|c|}
\hline Variable & $\begin{array}{c}\text { No } \\
\text { additive }\end{array}$ & P0 & $\mathrm{P} 1$ & $\mathrm{P} 2 \mathrm{a}$ & $\mathrm{P} 2 \mathrm{~b}$ & P3 & P4 & $\mathrm{LSD}_{0.05}$ \\
\hline $\mathrm{DM}, \mathrm{g} \mathrm{kg}^{-1}$ & $264^{b}$ & $268^{\mathrm{b}, \mathrm{a}}$ & $268^{\mathrm{b}, \mathrm{a}}$ & $269^{\mathrm{a}}$ & $270^{\mathrm{a}}$ & $270^{\mathrm{a}}$ & $269^{\mathrm{a}}$ & 4.994 \\
\hline $\mathrm{DM}, \%$ & $5.5^{\mathrm{a}}$ & $3.8^{\mathrm{b}}$ & $3.7^{\mathrm{c}, \mathrm{b}}$ & $3.5^{\mathrm{c}, \mathrm{b}, \mathrm{d}}$ & $3.1^{\mathrm{c}, \mathrm{d}}$ & $2.9^{\mathrm{d}}$ & $3.2^{\mathrm{c}, \mathrm{b}, \mathrm{d}}$ & 6.664 \\
\hline $\mathrm{pH}$ after 2 days & $4.26^{\mathrm{a}}$ & $4.11^{\mathrm{b}}$ & $4.06^{\mathrm{c}}$ & $4.01^{\mathrm{d}}$ & $4.08^{c}$ & $4.12^{\mathrm{b}}$ & $4.02^{\mathrm{d}}$ & 0.025 \\
\hline $\mathrm{pH}$ after 90 days & $3.74^{\mathrm{a}}$ & $3.64^{\mathrm{b}}$ & $3.57^{\mathrm{d}}$ & $3.59^{\mathrm{d}}$ & $3.61^{\mathrm{c}}$ & $3.61^{\mathrm{c}}$ & $3.63^{\mathrm{b}}$ & 0.018 \\
\hline Ammonia- $\mathrm{N}, \mathrm{g} \mathrm{kg}^{-1} \mathrm{~N}$ & $57.8^{\mathrm{a}}$ & $47.6^{\mathrm{b}}$ & $46.1^{\mathrm{b}}$ & $46.8^{b}$ & $40.7^{\mathrm{c}, \mathrm{b}}$ & $36.9^{c}$ & $39.7^{\mathrm{c}, \mathrm{b}}$ & 9.070 \\
\hline LA, $\mathrm{g} \mathrm{kg}^{-1} \mathrm{DM}$ & $56.18^{\mathrm{b}}$ & $49.52^{\mathrm{c}}$ & $55.68^{\mathrm{c}, \mathrm{b}}$ & $73.96^{\mathrm{a}}$ & $71.24^{\mathrm{a}}$ & $68.58^{\mathrm{a}}$ & $70.08^{\mathrm{a}}$ & 6.279 \\
\hline $\mathrm{AA}, \mathrm{g} \mathrm{kg}^{-1} \mathrm{DM}$ & $25.77^{\mathrm{c}}$ & $38.10^{\mathrm{a}}$ & $33.30^{\mathrm{b}}$ & $22.00^{\mathrm{d}}$ & $19.03^{\mathrm{e}}$ & $18.70^{\mathrm{e}}$ & $20.06^{\mathrm{ed}}$ & 2.232 \\
\hline $\mathrm{BA}, \mathrm{g} \mathrm{kg}^{-1} \mathrm{DM}$ & $0.45^{\mathrm{a}}$ & $0.10^{\mathrm{b}}$ & $0.07^{\mathrm{b}}$ & $0.03^{b}$ & $0.07^{\mathrm{b}}$ & $0.04^{\mathrm{b}}$ & $0.04^{\mathrm{b}}$ & 0.099 \\
\hline $\mathrm{PA}, \mathrm{g} \mathrm{kg}^{-1} \mathrm{DM}$ & $0.12^{\mathrm{b}}$ & $0.19^{\mathrm{b}, \mathrm{a}}$ & $0.21^{\mathrm{a}}$ & $0.12^{\mathrm{b}}$ & $0.13^{\mathrm{b}, \mathrm{a}}$ & $0.14^{\mathrm{b}, \mathrm{a}}$ & $0.13^{\mathrm{b}, \mathrm{a}}$ & 0.088 \\
\hline $\mathrm{AL}, \mathrm{g} \mathrm{kg}^{-1} \mathrm{DM}$ & $9.80^{\mathrm{a}}$ & $6.80^{\mathrm{b}}$ & $5.76^{\mathrm{c}}$ & $6.60^{\mathrm{b}}$ & $5.40^{\mathrm{c}}$ & $5.78^{\mathrm{c}}$ & $5.70^{\mathrm{c}}$ & 0.513 \\
\hline $\mathrm{CL}, \log \mathrm{cfu}^{-1} \mathrm{FM}$ & $1.00^{\mathrm{a}}$ & $0.99^{\mathrm{b}}$ & $0.99^{\mathrm{b}}$ & $0.99^{\mathrm{b}}$ & $0.99^{\mathrm{b}}$ & $0.99^{\mathrm{b}}$ & $0.99^{\mathrm{b}}$ & 0.004 \\
\hline $\mathrm{Y}, \log \mathrm{cfu} \mathrm{g}^{-1} \mathrm{FM}$ & $1.94^{\mathrm{a}}$ & $1.06^{\mathrm{b}}$ & $1.18^{\mathrm{b}}$ & $1.24^{\mathrm{b}}$ & $1.43^{\mathrm{b}, \mathrm{a}}$ & $1.32^{\mathrm{b}}$ & $1.37^{\mathrm{b}}$ & 0.565 \\
\hline $\mathrm{M}, \log \mathrm{cfu} \mathrm{g}^{-1} \mathrm{FM}$ & $2.01^{\mathrm{a}}$ & $1.00^{\mathrm{b}}$ & $1.12^{\mathrm{b}}$ & $1.28^{\mathrm{b}}$ & $1.39^{\mathrm{b}}$ & $1.18^{\mathrm{b}}$ & $1.25^{\mathrm{b}}$ & 0.502 \\
\hline
\end{tabular}

Explanations under Table 4

The treatments $\mathrm{P} 2 \mathrm{a}, \mathrm{P} 2 \mathrm{~b}, \mathrm{P} 3$ and $\mathrm{P} 4$ produce higher $(P<0.05)$ lactic acid concentration, lower $(P<0.05)$ acetic acid concentration compared with that of control

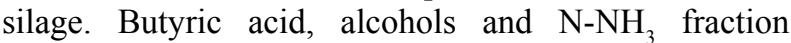
concentrations, yeast and mould counts were significantly decreased $(P<0.05)$ by all six products applied.

Aerobic stability of silages. During aerobic exposure untreated (no additive) ryegrass:timothy silage had a temperature rise of more than $3^{\circ} \mathrm{C}$ above the ambient after 96 h (Fig. 1). P2b, P3 and P4 silages had a temperature rise of more than $3^{\circ} \mathrm{C}$ above the ambient after $162 \mathrm{~h}$. P2a silages had a temperature rise of more than $3^{\circ} \mathrm{C}$ above the ambient after $174 \mathrm{~h}$. P1 silage had a temperature rise of more than $3^{\circ} \mathrm{C}$ above the ambient after $234 \mathrm{~h}$. P0 silage remained stable during the full aerobic stability measurement period $(312 \mathrm{~h})$. Therefore,

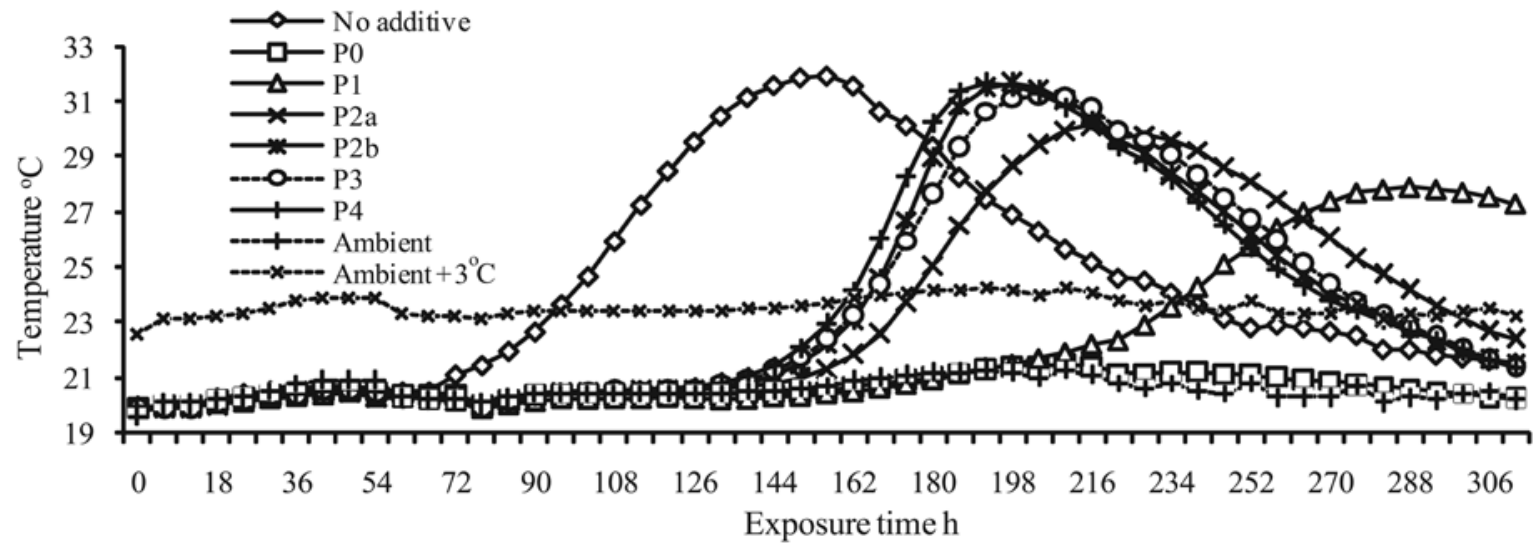

Figure 1. Aerobic stability of ryegrass:timothy silages untreated or treated with blends of bacterial strains and blend of bacterial strains in combination with sodium benzoate as silage inoculants

the aerobic stability of $\mathrm{P} 2 \mathrm{~b}, \mathrm{P} 3$ and $\mathrm{P} 4$ silages was improved by $2.7 \mathrm{~d}(66 \mathrm{~h})$, the aerobic stability of $\mathrm{P} 2 \mathrm{a}$ silage was improved by $3.2 \mathrm{~d}(78 \mathrm{~h})$, and the aerobic stability of P1 silage was improved by $5.7 \mathrm{~d}(138 \mathrm{~h})$ compared to control silage. Aerobic stability of P0 silage was improved dramatically.

During aerobic exposure untreated (no additive) whole crop maize silage had a temperature rise of more than $3^{\circ} \mathrm{C}$ above the ambient after $60 \mathrm{~h}$ (Fig. 2). P2b, $\mathrm{P} 4$, $\mathrm{P} 3, \mathrm{P} 1, \mathrm{P} 2 \mathrm{a}$ and $\mathrm{P} 0$ silages had a temperature rise of more than $3^{\circ} \mathrm{C}$ above the ambient after $78,78,96,138,144$ and $150 \mathrm{~h}$ respectively.

Aerobic stability of P2b, P4, P3, P1, P2a and P0 silages was improved by $0.75 \mathrm{~d}(18 \mathrm{~h})$, by $0.75 \mathrm{~d}(18 \mathrm{~h})$, by $1.5 \mathrm{~d}(36 \mathrm{~h})$, by $3.2 \mathrm{~d}(78 \mathrm{~h})$, by $3.5 \mathrm{~d}(84 \mathrm{~h})$ and by $3.75 \mathrm{~d}(90 \mathrm{~h})$, respectively compared to control silage.

\section{Discussion}

The ryegrass:timothy grass used in the experiment was only slightly wilted, resulting in a low dry matter concentration. It is advantageous if the inoculant succeeds also in high moisture conditions as weather conditions are not always optimal during harvest. The herbage contained a moderate concentration of WSC, which is typical of the plant species used. The mean DM concentration of the whole crop maize was $276 \mathrm{~g} \mathrm{~kg}^{-1}$, buffering capacity was $217 \mathrm{mEq} \mathrm{kg}{ }^{-1} \mathrm{DM}$. Ryegrass:timothy and whole crop maize silages treated 


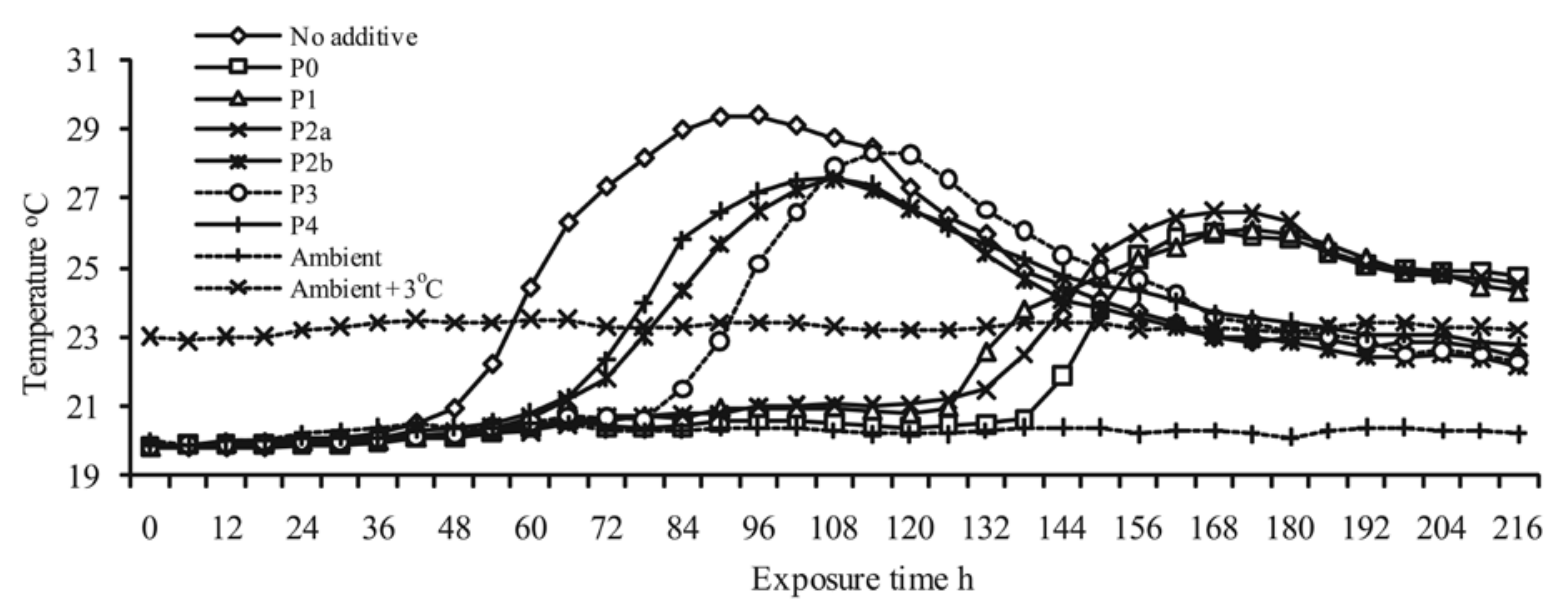

Figure 2. Aerobic stability of whole crop maize silages untreated or treated with blends of bacterial strains and blend of bacterial strains in combination with sodium benzoate as silage inoculants

with the tested inoculants were characterized by higher concentrations of DM compared with the untreated silage. This has also been confirmed by McDonald et al. (1991). In the present study, after 2-3 days of ensiling and at the end of the ensiling period ( 90 days), all LAB treatments significantly $(P<0.05)$ reduced $\mathrm{pH}$ relative to that of the control. Filya et al. (2007) concluded that main effects of silage inoculants were increased production of lactic acid connected with significant reduction of $\mathrm{pH}$ value and minimised dry matter losses. In our experiment, products used for the ryegrass:timothy and whole crop maize silage inoculation significantly $(P<0.05)$ decreased DM loss compared with control silage.

Ryegrass:timothy and whole crop maize silages inoculated with homofermentative LAB blends (P2a, P2b, P3 and P4) produced higher $(P<0.05)$ lactic acid concentration compared with that of the control silage. Such shifts (lower $\mathrm{pH}$ ) in silage fermentation with homofermentative LAB strains are consistent with the study of Filya et al. (2007) when such inoculants were successful. All six products tested in our experiment significantly decreased $(P<0.05)$ butyric acid, alcohols and $\mathrm{N}_{-} \mathrm{NH}_{3}$ fraction concentrations and significantly suppressed $(P<0.05)$ yeast and moulds count. Kleinschmit et al. (2005) found reduced fungal populations in silages treated with LAB additives. Knicky and Lingvall (2004) obtained reduction of yeast growth by application of sodium benzoate in both low and high DM red clover and timothy silages. In our experiment, the LAB blends or LAB blend in combination with sodium benzoate significantly suppressed yeast and mould growth reflected in the lower concentration of alcohols, generally correlated to yeast activity in silages. Recently, Prema et al. (2010) isolated Lactobacillus plantarum strain from grass silage that produced 3-phenillactic acid and demonstrated that this strain inhibited a wide range of mould species common to silage. Skytta et al. (2002) showed that a combination of a selected inoculant and sodium benzoate inhibited the growth of yeast isolated from grass silage.

In our experiment, silages treated with inoculants containing LAB strain L. buchnery ( $\mathrm{P} 0$ and $\mathrm{P} 1)$ significantly decreased lactic acid concentration and significantly increased acetic acid concentration. The reduction in the lactic acid with L. buchneri was reported by Reis et al., 2005. All six products tested in ryegrass:timothy and maize silages significantly reduced butyric acid and ammonia-N concentrations compared with control. The fermentation processes are possibly accelerated in the inoculated silages resulting in less proteolysis of plant proteins and ammonia- $\mathrm{N}$ concentrations. The positive effects of LAB inoculants on nitrogen fractions can be explained either by domination of the fermentation resulting in the rapid achievement of a low $\mathrm{pH}$ or via the low proteolytic activity of the strains. Saarisalo et al. (2007) indicated that L. plantarum strain was efficient in producing lactic acid, lowering $\mathrm{pH}$ rapidly and especially decreasing the ammonia- $\mathrm{N}$ production in silages.

The data presented in this report show that all six products used for inoculation increased the aerobic stability of ryegrass:timothy and whole crop maize silages, compared with control silage. P0 and P1 inoculants were more effective to increase aerobic stability of silages and to prevent aerobic deterioration. Therefore, L. buchneri (P0), L. buchneri in combination with homofermentative LAB (P1) as well as inoculation with homofermentative LAB in combination with sodium benzoate (P2a) was most effective in decreasing aerobic deterioration in ryegrass:timothy and maize silages. Studies (Reis et al., 2005; Danner et al., 2003) provide more definitive evidence for the existence of certain LAB strains with the power to inhibit yeast and moulds growth, to control temperature during aerobic exposure and to improve aerobic stability. The improvement of aerobic stability was observed in a timothy:meadow fescue silage by using L. buchneri or sodium benzoate in combination with L. plantarum (Jaakkola et al., 2010). Danner et al. (2003) investigated the effect of different compounds formed by heterofermentative LAB on aerobic stability of silage and concluded that aerobic stability was directly correlated to the amount of acetic acid present in silages. The amount of undissociated acetic acid has been identified as the most important factor to consider when attempting inhibiting yeast growth in silages (Danner et al., 2003). Broberg et al. (2007) and Ratanapibulsawat et al. (2005) have isolated $1 \mathrm{LAB}$ strains from silages that produce inhibitory activity against a variety undesirable bacterial species and improve aerobic stability of the silages. 


\section{Conclusions}

1. In this study, the addition of the blends of selected bacterial strains and blend of selected bacterial strains in combination with sodium benzoate as silage inoculants reduced the $\mathrm{pH}$ of the ryegrass:timothy and whole crop maize silages and improved silage quality. Inoculants were efficient in improving fermentation, reducing protein breakdown as well as dry matter losses of ryegrass:timothy and whole crop maize silages.

2. Homofermentative lactic acid bacteria (LAB) and homofermentative LAB in combination with sodium benzoate led to silages with higher lactic acid concentration. Inoculation with single heterofermentative LAB strain or heterofermentative LAB strain in combination with homofermentative $\mathrm{LAB}$ resulted in higher levels of acetic acid.

3. An enhancement in microbial quality and aerobic stability was obtained in all inoculated silages. Single strain of Lactobacillus buchneri or L. buchneri in combination with homofermentative LAB as well as inoculation with homofermentative LAB in combination with sodium benzoate was most effective in improving aerobic stability of ryegrass:timothy and whole crop maize silages.

Received 15102012 Accepted 14022013

\section{References}

Broberg A., Jacobsson K., Strom K., Schnurer J. 2007. Metabolite profiles of lactic acid bacteria in grass silage. Applied and Environmental Microbiology, 73: 5547-5552 http://dx.doi.org/10.1128/AEM.02939-06

Contreras-Govea F. E., Muck R. E., Broderick G. A., Weimer P. J. 2009. Lactobacillus plantarum MTD/1, its impact on silage and in vitro rumen fermentation. $15^{\text {th }}$ International Silage Conference 2009. Madison, USA, p. 57-58

Danner H., Holzer M., Mayrhuber E., Braun R. 2003. Acetic acid increases stability of silage under aerobic conditions. Applied and Environmental Microbiology, 69: 562-567 http://dx.doi.org/10.1128/AEM.69.1.562-567.2003

Davies D. R., Theodorou M. K., Kingston-Smith A. H., Merry R. J. 2005. Advances in silage quality in the $21^{\text {st }}$ century. $14^{\text {th }}$ International Silage Conference. Belfast, Northern Ireland, p. 121-133

Dolci P., Tabacco E. Cocolin L., Borreani G. 2011. Microbial dynamics during aerobic exposure of corn silage stored under oxygen barrier or polyethylene films. Applied and Environmental Microbiology, 77: 7499-7507 http://dx.doi.org/10.1128/AEM.05050-11

Filya I., Muck R. E., Contreras-Govea F. E. 2007. Inoculant effects on alfalfa silage: fermentation products and nutritive value. Journal of Dairy Science, 90: 5108-5114 http://dx.doi.org/10.3168/jds.2006-877

Gollop N., Zakin V., Weinberg Z. 2005. Antibacerial activity of lactic acid bacteria included in inoculants for silage and in silages treated with these inoculants. Journal of Applied Microbiology, 98: 662-666 http://dx.doi.org/10.1111/j.1365-2672.2004.02504.x

Jaakkola S., Saarisalo E., Heikkila T. 2010. Aerobic stability and fermentation quality of round bale silage treated with inoculants or propionic acid. $23^{\text {rd }}$ General Meeting of the European Grassland Federation. Kiel, Germany, p. $503-505$
Jatkauskas J., Vrotniakiene V., Ohlsson C., Lund B. 2013. The effects of three silage inoculants on aerobic stability in grass, clover grass, lucerne and maize silages. Agricultural and Food Science, 22: 137-144

Kleinschmit D. H., Schmidt R. J., Kung J. R. L. 2005. The effects of various antifungal additives on the fermentation and aerobic stability of corn silage. Journal of Dairy Science, 88: 2130-2139 http://dx.doi.org/10.3168/jds.S0022-0302(05)72889-7

Knicky M., Lingvall P. 2004. Ensiling of high wilted grassclover mixture by use of different additives to improve quality. Acta Agriculturae Scandinavica, Section A: Animal Science, 54 (4): 197-205 http://dx.doi.org/10.1080/09064700410010017

Krizsan S., Randby A. 2007. The utilization of multidimensional scaling to identify forage characteristics associated with preference in sheep. Journal of Animal Science, 75: $1641-1650$

Leuschner R. G. K., Jan B., Paul S. J., Ross P. R., Stanton C. 2003. Enumeration of probiotic pediococci in animal feed: interlaboratory study. Journal of AOAC International, 86 (4): 791-801

McDonald P., Henderson A. R., Heron S. J. E. 1991. The biochemistry of silage. Marlow, UK, $340 \mathrm{p}$ -

Moran J. P., Weinberg Z. G., Ashbell G., Hen Y., Owen T. R. 1996. A comparison of two methods for the evaluation of the aerobic stability of whole crop wheat silage. $11^{\text {th }}$ International Silage Conference. Aberystwyth, Wales, UK, p. $162-163$

Muck R. 2012. Microbiology of ensiling. $16^{\text {th }}$ International Silage Conference. Hameelinna, Finland, p. 75-86

Pahlow G., Muck R. E., Driehuis F., Oude Elferink S. J. W. H., Spoelstra S. F. 2003. Microbiology of ensiling. Silage Science and Technology, 42: 31-93

Prema P., Smila D., Palavesam A., Immanuel G. 2010. Production and characterization of an antifungal compound (3-phenyllactic acid) produced by Lactobacillus plantarum strain. Food and Bioprocess Technology, 3: 379-386 http://dx.doi.org/10.1007/s11947-008-0127-1

Ratanapibulsawat C., Kroujkaew P., Sadahiro O., Nitisinprasert S. 2005. Screening and characterization of lactic acid bacteria producing antimicrobial substance against Staphylococcus aureus. Kasetsart Journal: Natural Sciences, 39: 284-293

Reis R., Almeida E., Siqueira G., Bernardes E. R., Janusckiewicz E. 2005. Microbial changes and aerobic stability in high moisture maize silages inoculated with Lactobacillus buchnery. $14^{\text {th }}$ International Silage Conference. Belfast, Northen Ireland, p. 223

Saarisalo E., Skytta E., Haikara A., Jalava T., Jaakkola S. 2007. Screening and selection of lactic acid bacteria strains suitable for ensiling grass. Journal of Applied Microbiology, 102: 327-336 http://dx.doi.org/10.1111/j.1365-2672.2006.03103.x

Skytta E., Haikara A., Saarisalo E., Jaakola S. 2002. Inhibition of aerobic spoilage yeasts in silage by hurdle technology. $13^{\text {th }}$ International Silage Conference. SAC. Auchincruive, Scotland, UK, p. 184-185

Statistical Analysis System. 2000. User's guide: Statistics, version 8.02. SAS Institute Inc. Cary, USA

Van Soest P. H., Robertson J. B., Lewis B. A. 1991. Methods for dietary fiber, neutral detergent fiber, and nonstarch polysaccharides in relation to animal nutrition. Journal of Dairy Science, 74: 3583-3597 http://dx.doi.org/10.3168/jds.S0022-0302(91)78551-2 
Weib K., Gerlach K., Sudekum K.-H. 2011.Fluchtige Substanzen in Maissilagen in Abhangigkeit von Silierbedingungen und aerober Laerungsdauer. Kongressband, VDLUFASchriftenreihe 67, p. 534-540 (in German)
Wichert B., Kienzle E., Bauer J. 1998. Palatability and intake of silage in dairy cows, in relation to hygienic quality. Journal of Animal Physiology and Animal Nutrition, 80: 253-259 http://dx.doi.org/10.1111/j.1439-0396.1998.tb00538.x

ISSN 1392-3196 / e-ISSN 2335-8947

Zemdirbyste-Agriculture, vol. 100, No. 2 (2013), p. 143-150

DOI $10.13080 /$ z-a.2013.100.018

\title{
Žolių ir kukurūzų siloso su inokuliantų priedu fermentacijos rodikliai, mikrobiologinè sudėtis bei aerobinis stabilumas
}

\author{
J. Jatkauskas, V. Vrotniakienè \\ Lietuvos sveikatos mokslų universiteto Gyvulininkystės institutas
}

\begin{abstract}
Santrauka
Siekiant nustatyti inokuliantų (pieno rūgšties bakterijų mišinio arba šių bakterijų mišinio su natrio benzoatu) ịtaką miglinių žolių ir kukurūzų vegetacinès masės siloso fermentacijos rodikliams, mikrobiologinei kokybei bei aerobiniam stabilumui, 2011-2012 m. atlikti du bandymai. Silosas buvo pagamintas laboratorinemis sąlygomis iš daugiamečių svidrių ir motiejukų mišinio, pavytinto iki $265 \mathrm{~g} \mathrm{~kg}^{-1}$ sausųjų medžiagų (SM) ir kukurūzų vegetacinès masès, turinčios $276 \mathrm{~g} \mathrm{~kg}^{-1} \mathrm{SM}$. Žolių mišinyje buvo $101,8 \mathrm{~g} \mathrm{~kg}^{-1} \mathrm{SM}$ vandenyje tirpių angliavandenių (VTA), buferinè talpa siekè $355 \mathrm{mEq} \mathrm{kg}{ }^{-1} \mathrm{SM}$, nitratų koncentracija - 153,2 $\mathrm{mg} \mathrm{kg}^{-1} \mathrm{SM}$. Kukurūzų vegetacinèje masèje buvo 98,9 $\mathrm{g} \mathrm{kg}^{-1} \mathrm{SM}$ VTA, buferinè talpa sieké $217 \mathrm{mEq} \mathrm{kg}{ }^{-1} \mathrm{SM}$, nitratų koncentracija $-841,1 \mathrm{mg} \mathrm{kg}^{-1} \mathrm{SM}$. Naudoti inokuliantai ir miglinių žolių, ir kukurūzų vegetacinès masės silose padidino sausujų medžiagų kiekį, esmingai $(P<0,05)$ sumažino siloso $\mathrm{pH}$ rodiklį, sviesto rūgšties kiekị, amoniakinio azoto koncentraciją ir sausųjų medžiagų nuostolius. Daugiamečių svidrių bei motiejukų mišinio žolès ir kukurūzų vegetacinès masès silose, apdorotame homofermentinių bakterijų mišiniu, buvo daugiau $(P<0,05)$ pieno rūgšties, palyginus su silosu be priedų. Heterofermenentatyvinių pieno rūgšties bakterijų priedas Lactobacillus buchnery silose padidino $(P<0,05)$ acto rūgšties koncentraciją ir sumažino pieno rūgšties koncentraciją. Naudoti inokuliantai esmingai $(P<0,05)$ slopino mielių bei pelèsių augimą ir mažino alkoholio koncentraciją. Silosavimo priedai miglinių žolių ir kukurūzų vegetacinès masės siloso aerobinị stabilumą padidino 66-312 valandų.
\end{abstract}

Reikšminai žodžiai: aerobinis stabilumas, fermentacija, kukurūzai, mikrobinis inokuliantas, motiejukai, silosas, svidrès. 